\title{
References
}

1. Nersesyants, V. S. (1998). History of Political and Legal Doctrines. Moscow: INFRA [in Russian].

2. Spectorskyi, E. V. (1911). The Concept of the Society in the Ancient World. Warsaw [in Russian].

3. Svintsov, V. I. (1994). True, Which is not True. Svobodnaya myisl, № 2 [in Russian].

4. Frazer, J. (2nd ed.). (1983). Golden Branch: Study of Magic and Religion. Moscow: Politizdat [in Russian].

5. Petrov, R. V. (1986). Immunology. Moscow : Medicine [in Russian].

6. Mak Innis, R. (1999). Moral Origin of Human Nature.(V. Y. Vasilieva, Trans.). Kyiv: B.I. [in Russian].

УДК 316.77:17.011.1:38

Vasylenko Valeriia,

Information Supply Officer of Vasyl' Stus Donetsk National University v.vasilenko@donnu.edu.ua https://orcid.org/0000-0002-2370-5615

\section{PECULIARITIES OF USING SOCIO-COMMUNICATION TECHNOLOGIES IN THE PROCESS OF DEVELOPING POSITIVE IMAGE OF A HIGHER EDUCATION INSTITUTION}

The purpose of the present article is to define the peculiarities of applying the socio-communicative technologies in the formation of positive image of a higher education institution. The methodology of the research is based on the general scientific and special methods of cognition such us analysis, synthesis, logical method, monitoring and the method of visualization of the research results. The scientific novelty lies in the fact that components of the higher education institution image creation are investigated in the context of their qualitative and quantitative indicators. The peculiarities of applying socio-communication technologies in the process of developing a higher education institution's positive image are determined. In the conclusions the author determines that in the process of developing a unique, emotionally-colored image of an institution of higher education in the consciousness of its target audience, it is necessary to take into account certain peculiarities of using socio-communicational technologies such as the coverage of scientific activity of teachers and students of the HEI, operational updating and provision of information on general issues about educational activity, development and support of social activity of the institution, the opportunity to present a visual demonstration of teacher's pedagogical abilities, advertising and increasing the popularity of the HEI, forming a positive attitude towards the organization of educational process.

Key words: positive image, higher education institution, socio-communicative technologies.

Василенко Валерія Юріївна, спеціаліст з інформаційного забезпечення Донецького національного університету імені Василя Стуса

\section{ОСОБЛИВОСТІ ВИКОРИСТАННЯ СОЦІОКОМУНІКАЦІЙНИХ ТЕХНОЛОГІЙ ПРИ ФОРМУВАННІ ПОЗИТИВНОГО ІМІДЖУ ЗАКЛАДУ ВИЩОЇ ОСВІТИ}

\footnotetext{
Мета дослідження. Визначити особливості використання соціокомунікаційних технологій при формуванні позитивного іміджу закладу вищої освіти. Методологія дослідження базується на застосуванні загальнонаукових та спеціальних методів пізнання, зокрема аналізу, синтезу, логічного методу, моніторингу та методу візуалізаџї результатів дослідження. Наукова новизна. Розглянуто
} 
складові формування іміджу закладу вищої освіти в контексті їх якісних та кількісних показників. Визначені особливості використання соціокомунікаційних технологій при формуванні позитивного іміджу освітнього закладу. Висновки. Визначено, щзо при створенні унікального, емоиійнозабарвленого образу закладу вищої освіти в свідомості своєї иільової аудиторії необхідно враховувати певні особливості використання соиіокомунікаційних технологій, а саме: висвітлення інформації про наукову діяльність викладачів та студентів ЗВО, оперативне оновлення та надання інформації щодо загальних питань з освітньої діяльності, створення та підтримка соціальної активності закладу, можливість представлення наочного демонстрування педагогічних здібностей викладача, рекламування та підвищення популярності ЗВО, формування позитивного відномення студентів до організачії навчання.

Ключові слова: позитивний імідж, заклад вищої освіти, соџіокомунікаційні технології.

Василенко Валерия Юрьевна, специалист по информационному обеспечению Донецкого национального университета имени Василя Стуса

\section{ОСОБЕННОСТИ ИСПОЛЬЗОВАНИЯ СОЦИОКОММУНИКАЦИОННЫХ ТЕХНОЛОГИЙ ПРИ ФОРМИРОВАНИИ ПОЗИТИВНОГО ИМИДЖА УЧРЕЖДЕНИЯ ВЫСШЕГО ОБРАЗОВАНИЯ}

Цель исследования. Определить особенности использования социокоммуникационных технологий при формировании положительного имиджа учреждения высшего образования. Методология исследования базируется на применении общенаучных и специальных методов познания, $в$ частности анализа, синтеза, логического метода, мониторинга и метода визуализации результатов исследования. Научная новизна. Рассмотрены составляющие формирования имиджа учреждения выстего образования в контексте их качественных и количественных показателей. Определены особенности использования сочиокоммуникачионных технологий при формировании положительного имиджа образовательного учреждения. Выводы. Определено, что при создании уникального, эмочионально-окраменного образа учреждения выстего образования в сознании своей целевой аудитории необходимо учитывать определенные особенности использования сочиокоммуникационных технологий, а именно: освещение информачии о научной деятельности преподавателей и студентов УВО, оперативное обновление и предоставление информации по общим вопросам об образовательной деятельности, создание и поддержка сочиальной активности заведения, возможность представления наглядной демонстрации педагогических способностей преподавателя, рекламирование и повышение популярности УВО, формирование положительного отношения студентов к организации обучения.

Ключевые слова: положительный имидж, учреждение выстего образования, социокоммуникационные технологии.

Urgency of the research. Nowadays, many higher education institutions (HEI) constantly have to face certain difficulties in implementation of their educational activity. First of all, these difficulties are caused by the demographic crisis in Ukraine, decline in the popularity of Ukrainian education, lack of operational information to university entrants on annual changes in the rules of admission to higher education institutions, short supply to "non-prestigious" specialities in the natural sciences (such as "Chemistry", "Physics", "Biology"), lack of funding from the Ministry of Education, etc.
The current situation requires from higher education institutions the system transformation, creation of such conditions of operation, in which the Ukrainian HEI will be recognized and have high authority among competitors and their target audience. Implementation of these conditions is impossible without creating a unique image of the institution.

Among the existing tools and instruments of creation of a positive image, the primary role should be allocated to the use of socio-communication technologies. It is socio-communication technologies, which are an innovative tool that, 
during the transition to the information society, enables the use of modern information technologies for manipulating the consciousness of people, and creating a favorable positive impression on the higher education institution among its target audience.

Analysis of recent researches and publications. The issue of forming an image as a component of the competitiveness of a higher education institution and an aspect of growth of its economic indicators is considered in the works both of domestic $[6,8,10]$ and foreign authors $[1,3]$.

N.V. Horbenko [12], in her work, emphasizes the fact that the image of a higher education institution should be focused on the end user of services provided by the education institution and subordinated to the necessity to capture his desire and the mood of perception.

The problem of formation of a personal (individual) image of a person as one of the main components of formation of the corporate image of a higher education institution in the system of social communications is considered by the author K.V. Diuzheva [13]; the definition of main components of the image of an education institution and the development of practical recommendations for its formation are noted in the works of Yu.M. Karpenko and N.L Karpenko [14], N.V. Mamai [16]; Sung-Un Yang, Minjung Sung [4] consider the formation of a university image through the prism of influence of the identity brand, external prestige and reputation.

The peculiarities of the technology of forming an image as one of the types of socio-communication technologies are considered in the work of O.M. Kholod [17]. The use of such Internet technologies as a website, a virtual library, a system of online education Moodle and their influence on the image formation of an education institution is noted in the work of M.S. Kovalchuk [15].

$\square$ tefan Vlăduțescu [5] analyzes the use of social networks as a basis for socio-communication activity and Janet Fulk [2] defines the use of modern communication technologies in social activity of society.

These authors studied a wide range of issues on the mentioned subject. However, the process of the image formation of a higher education institution, taking into account the peculiarities of applying socio-communicational technologies in the modern information space, has not been fully investigated and it has determined the purpose of this research.

Purpose of the article is to determine the peculiarities of the use of socio-communication technologies in the formation of a positive image of a higher education institution.

Presentation of basic materials. At present, the image of a higher education institution is perceived as an image, which has an emotional color created in the public consciousness. Such image is determined by a certain correlation between the various aspects of activity of this institution and is transmitted to the external environment [7].

Consequently, the image is a "marketing instrument, which must be precisely targeted at the end consumer and subordinated to the desire to capture his wish and changes in mood and social status" [12].

The peculiarity of formation of a positive image of a higher education institution is the filling with the positive content of the institution's image that, in its turn, influences on the growth of trust in it, increase of prestige, authority and sphere of influence [16].

The process of the image formation of a higher education institution will be considered from the standpoint of the main goal of HEI itself. The main goal is to provide educational services. Therefore, the image of educational services is an obligatory component of the image of a higher education institution. It is also necessary to specify the subjects of activity: who provides educational services and to whom they are provided. "Who provides" refers directly HEI and its professorial teaching staff (PTS); "To whom it is provided" - students.

Thus, the process of the image formation of a higher education institution, according to the author, consists of the image of educational services, the image of HEI itself, the image of the PTS and the image of students.

Let us consider each of these components in the context of their qualitative and quantitative indicators (Table 1). 
Table 1 - Indicators of the main components of the image formation of a higher education institution

\begin{tabular}{|c|c|c|c|}
\hline No. & $\begin{array}{c}\text { A component } \\
\text { of the image } \\
\text { formation of } \\
\text { HEI }\end{array}$ & Quantitative indicators & Qualitative indicators \\
\hline 1 & $\begin{array}{l}\text { The image of } \\
\text { e d u c a t i o n a } 1 \\
\text { services }\end{array}$ & $\begin{array}{l}\text { number of specialities; price for the } \\
\text { year of study depending on the chosen } \\
\text { speciality, educationaldegree(bachelor, } \\
\text { master), forms of study; number of } \\
\text { classroom (lecture, practical) hours for } \\
\text { each discipline }\end{array}$ & $\begin{array}{l}\text { according to which directions of training } \\
\text { higher education is provided; available } \\
\text { forms of study (full-time, part-time, } \\
\text { online); what disciplines are taught in } \\
\text { each speciality (on each course), their } \\
\text { content part; quality of the knowledge } \\
\text { provided }\end{array}$ \\
\hline 2 & $\begin{array}{l}\text { The image of a } \\
\text { higher education } \\
\text { institution itself }\end{array}$ & $\begin{array}{l}\text { number of graduating departments/ } \\
\text { faculties/scientific institutes; number } \\
\text { of educational buildings; number } \\
\text { of dormitories; number of students } \\
\text { enrolled by the Admission Committee; } \\
\text { the place among All-Ukrainian/ } \\
\text { International ratings of HEI; number } \\
\text { of educational/computer classrooms; } \\
\text { distance of dormitories from } \\
\text { educational buildings; distance of } \\
\text { educational buildings from each other/ } \\
\text { from the city center; amount of salaries } \\
\text { of lecturers/student scholarships; } \\
\text { proportion of "lost" students during } \\
\text { the academic year }\end{array}$ & $\begin{array}{l}\text { availability of attributes (anthem, } \\
\text { emblem and flag); holding traditional } \\
\text { holidays (First-Year Debut, Faculty } \\
\text { Day, Student's Day, etc.); carrying out } \\
\text { of scientific conferences; availability } \\
\text { of scientific/professional publications; } \\
\text { participation in regional/All-Ukrainian/ } \\
\text { International projects }\end{array}$ \\
\hline 3 & $\begin{array}{l}\text { The image of } \\
\text { the professional } \\
\text { teaching staff }\end{array}$ & $\begin{array}{l}\text { number of lecturers with a degree } \\
\text { (candidate/doctor of sciences) and } \\
\text { degree (Doctor/Professor); number of } \\
\text { members of the Academy of Sciences; } \\
\text { number of lecturers with knowledge } \\
\text { of a foreign language of level B2 and } \\
\text { above; number of scientific works } \\
\text { in professional/foreign publications; } \\
\text { work experience (number of years); } \\
\text { number of female/male lecturers }\end{array}$ & $\begin{array}{l}\text { compliance with certain requirements } \\
\text { and standards in teaching; lecturer's } \\
\text { satisfaction level; availability of } \\
\text { advanced training; previous experience } \\
\text { (in which institutions worked, on which } \\
\text { positions) }\end{array}$ \\
\hline 4 & $\begin{array}{l}\text { The image of a } \\
\text { student }\end{array}$ & $\begin{array}{l}\text { number of first-year students, who } \\
\text { entered HEI with excellent independent } \\
\text { external evaluation; number of } \\
\text { scientific works in professional/foreign } \\
\text { publications; number of employed } \\
\text { students (graduates) in the specialty; } \\
\text { number of foreign students }\end{array}$ & $\begin{array}{l}\text { participation of students in the } \\
\text { regional, All-Ukrainian, International } \\
\text { conferences/olympiads; student's } \\
\text { satisfaction level; rating of studying } \\
\text { students; from which schools the } \\
\text { students entered HEI, in which } \\
\text { specialities. }\end{array}$ \\
\hline
\end{tabular}

It should be noted that the formation of a positive image of a higher education institution is accompanied by some targeted information work. In the modern informational and educational environment, the implementation of such work is impossible without the use of socio-communication technologies (SCT).
Therefore, D. Gavra notes that socio-communicational technologies represent a targeted, systematically organized activity, which has an action plan and is aimed at solving socially important problems [11].

Stages of development of socio-communicational technologies are given in Fig. 1. 


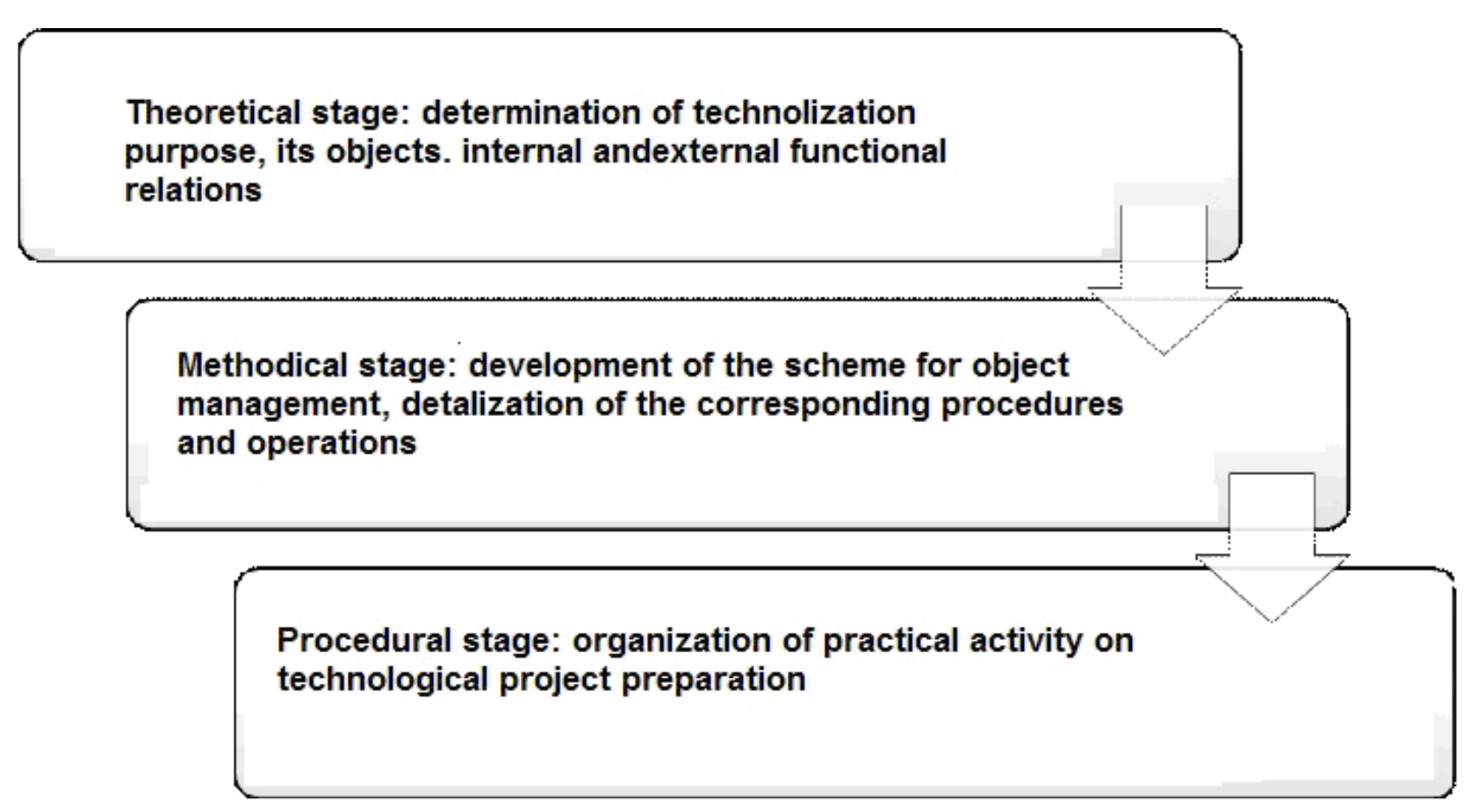

Figure 1 - Stages of development of socio-communicational technologies

Let us distinguish one more definition of the concept of socio-communication technologies, which is more appropriate to use in the process of formation of a positive image of a higher education institution. According to the author O. Kholod, socio-communication technologies mean "a system of manipulative action-complexes, aimed at changing the behavior of society" [17].

One of the types of socio-communication technologies is the technology of formation of an image, the main purpose of which is to create the necessary image of the person involved (a person, a social institution, a country, etc.) with the help of various action-complexes [17].

Let us consider peculiarities of the use of socio-communication technologies in formation of one of the main components of formation of the image of a higher education institution - the image of educational services.

Name of SCT: website of an education institution.

Peculiarities of the use. Highlighting of information by providing a common access to operative curricula for each academic year, each speciality. The operative curriculum, which is scanned and posted on the official website of an education institution, provides information on the names of disciplines, in which semester they are studied and how many hours are devoted to them.

Transparency in the implementation of educational services is ensured by providing a common access to prices (a price list) for each year of study in the chosen speciality signed by the head of HEI.

Name of SCT: online learning platform (e.g., EFront, Moodle, Mirapolis Learning Management System).

Peculiarities of the use. Every year online education is becoming increasingly popular in both the European and the Ukrainian educational community. Provision of educational services for the online learning students (without excluding both part-time and full-time forms) is possible, if there are courses developed on certain educational platforms. To inform entrants and their parents about the content of courses studied in a particular speciality, the teacher can provide a guest access not only for students, but also for other groups of users. In addition, in order to avoid possible corruption schemes on the part of the lecturer, students of the online educational platform can see the results of estimation for both their work and 
the work of their group mates (using the object "Journal of Grades").

Another element of formation of the image of an education institution is the image of a higher education institution itself, the peculiarities of which are discussed below.

Name of SCT: website of an education institution.

Peculiarities of the use. The website should include the faculty pages, which will cover the basic information about their activity and contacts for communication. The standard structure of the faculty page on the official website of HEI can consist of the following elements: general information about the faculty (year of foundation, location, history); structure of the dean's office: full names of the staff, positions, contacts; the list of departments with the specialities they produce, the structure of the departments: full names of the head and lecturers with all the academic titles and scientific degrees. Thus, the target audience (entrants, partners, other HEIs) will be able to immediately contact the faculty management/ employees to resolve the existing issues.

Highlighting of information on scientific activity is possible through the placement of announcements about conferences, Olympiads and other scientific events in the newsfeed on the first page of the website.

A positive moment may also lie in the operational update and provision of information on the first page of the website on the list of entrants during the admission campaign of education institutions.

Name of SCT: social networks.

Peculiarities of the use. Creation and support of social activity of a higher education institution is possible through the use of information resources of social networks: groups in Facebook, official pages in Instagram, channels in Telegram. To attract and maintain the attention of the target audience, it is necessary that the frequency of records in the above resources must be not less than 1-2 times for two days. In this case, the content must be linked:

1) with the university life: highlighting of information on the official events, holidays, days of open doors with indication of time and place of holding;

2) with the results of scientific achievements of lecturers and students: highlighting of information on internship abroad or winning in various competitions and olympiads;

3) with information on general issues related to educational activity, changes in the rules of the admission committee regarding admission to HEI, etc. [9].

Obligatory conditions for creation and distribution of such records shall include the indication of an official source, the addition of photo, video and audio content to attract the attention of the audience, the ability to add comments, so that users can evaluate entries or ask clarification questions to the administrator.

Name of SCT: periodicals.

Peculiarities of the use. Availability of the conference collections of local, regional, AllUkrainian and international levels, scientific/professional journals and newspapers give a higher education institution the opportunity to cover the results of scientific activity and scientific achievements of the professional teaching staff, employees of a higher education institution, students and education grantees. Another advantage is the ability to establish partner/friend relationships with scholars in various fields, with other partner education institutions by providing the opportunity to be published in their scientific collections, thereby promoting and increasing the popularity of collections, as well as HEIs, in which they are printed.

Peculiarities of the use of the socio-communication technologies of the image of the professional teaching staff is presented below.

Name of SCT: information resources for tracking citation of scientific publications.

Peculiarities of the use. One of the indicators for assessing the quality of the scientific activity of the professional teaching staff is citation of its articles. For example, if a teacher has his own account in Google Scholar, then any Internet user will be able to find out the information about citation of his scientific publications and their indexing in the Google Scholar search engine. Another tool for tracking citation of scientific articles is the international scientific database Scopus. Functional features of such database are similar to Google Scholar: if a lecturer has his own account in Scopus, then it is possible to track citation of his articles in Scopus and Web of Science journals. It should be noted that the more lecturer's scientific 
papers are cited, the greater authority and respect he has in the scientific society.

Name of SCT: social networks.

Peculiarities of the use. The lecturers' personal pages in social networks, the groups they are subscribed to, the list of their "virtual" friends - all this allows the users, including students, university entrants, their parents and other HEI employees, to learn more about the personal life of lecturers, their interests and preferences. This information can almost always be found in open access, so lecturers need to be more closely related to the content of records they publish, what they comment on and, if there is a need and opportunity, to hide the page from visitors, to add only proven users to friends.

To clearly demonstrate his pedagogical abilities, the lecturer can record video lectures and put them on his own channel on YouTube (for example, within YouTube channel of the faculty or university). As part of such video lecture, the lecturer will be able to demonstrate his oratorical abilities, the level of knowledge of the material and the availability of studying the questions raised. After watching a video lecture, the users will be able to leave their comments/ wishes about the submitted materials, and the lecturer will be able to make a choice: to follow them or not.

Let us consider the formation of a student's image using socio-communication technologies. stitution.

Name of SCT: website of an education in-

Peculiarities of the use. A student's academic success is a key to the effectiveness of studying at HEI. Highlighting of the students' academic achievement may be possible by providing access to the student progress rating by the results of session in the newsfeed on the main page of the website.

Timely presentation of information on the academic progress of all students, in the open access, demonstrates the transparency of the examination session at a higher education institution and ensures the formation of a positive attitude of students towards arrangement of studying at HEI.

To create the interest of the target audience to certain specialities by eliminating ambiguities regarding the questions of future employment from prospective students and their parents, it is possible to provide information about successful graduates with their full names, their specialities, the year of graduation and the place of employment, stating the occupied position, on the pages of faculties of HEI.

Scientific novelty. The components of formation of the image of a higher education institution in the context of their qualitative and quantitative indicators have been considered. The peculiarities of the use of socio-communication technologies in the formation of a positive image of an education institution have been mentioned.

Summarizing the above, one can conclude that the process of formation of a positive image of a higher education institution in the modern informational and educational environment is accompanied by the use of such socio-communicational technologies as an educational institution's website, online learning platform, social resources of social networks, periodicals, information resources for tracking citation of scientific publications.

It should be mentioned that when creating a unique, emotionally colored image of a higher education institution in the consciousness of its target audience, it is necessary to take into account certain peculiarities of the use of represented socio-communication technologies, namely: highlighting of information on the scientific activity of lecturers and students of HEI, operational update and provision of information on general issues of educational activity, creation and support of social activity of the institution, opportunity to present a visual demonstration of the lecturer's pedagogical abilities, advertising and increasing the popularity of HEI, formation of a positive attitude of students towards the arrangement of studying. 


\section{Список використаних джерел}

1. Drūteikenè G., Marčinskas A. University image: new approach and perspective theoretical and practical. Ekonomika. 2011. Vol. 90, № 2. P. 161-164.

2. Fulk J. Social Construction of Communication Technology. The Academy of Management Journal. 1993. Vol. 36, № 5. P. 921-950.

3. Prez J. P., Torres E.M. Evaluation of the organizational image of a university in a higher education institution. Contadur?a y Administraci?n. 2017. Vol. 62, № 1. P. 123-140.

4. Sung M., Yang S. Toward the Model of University Image: The Influence of Brand Personality, External Prestige, and Reputation. Journal of Public Relations Research. 2008. Vol. 20, № 4. P. 357-376.

5. Vlăduțescu. Communicational Basis of Social Networks. International Journal of Management Sciences and Business Research. 2013. Vol. 2, № 8. P. 1-5.

6. Ананченкова П. И. Совершенствование имиджа как фактор конкурентоспособности высшего учебного заведения : дис. канд. эк. наук : 08.00.05. Москва, 2009. 163 с.

7. Арбузова Ю. В. Формування позитивного іміджу навчального закладу. Інформаційні технології в науці та виробництві. 2014. № 2 (10). URL: http://sbornik.college.ks.ua/downloads/sbornik2_7/pdf/29.pdf (дата звернення 02.01.2019).

8. Бачинська О.М. Роль іміджу в структурі забезпечення конкурентоспроможності ВНЗ. Актуальні питання підвищення конкурентоспроможності держави, бізнесу та освіти в сучасних економічних умовах : зб. матеріалів I Міжнар. науково-практ. Інтернет-конф. 2013. URL: http://www.confcontact. com/20130214_econ/4_bachinska.htm (дата звернення 02.01.2019).

9. Василенко В. Використання інформаційних ресурсів соціальних мереж для професійно орієнтованої роботи ВНЗ. Проблеми формування інформаційної культури особистості : зб. матер. Всеукр. наук.-практ. конф. з міжнародною участю. Маріуполь : МДУ, 2013. - С. 180.

10.ВолковаВ.В.Имиджобразовательногоучреждениявконтекстепроблемыконкурентоспособности вузов. Сб. науч. тр. Северо-Кавказского гос. техн. ун-та. 2005. Вип. 2. URL: http://science.ncstu.ru/articles/ hs/14/10.pdf/file_download (дата звернення 05.01.2019).

11. Гавра Д. Социально-коммуникативные технологии: сущность, структура, функции. Оптимальные коммуникации. URL: http://jarki.ru/wpress/2010/02/28/937/ (дата звернення 10.01.2019).

12. Горбенко Н. В. Особливості формування іміджу сучасного університету. Освітологічний дискурс. 2014. № 1(5). С. 36-43.

13. Дюжева К.В. Формування іміджу в системі соціальних. Соціум. Документ. Комунікація. 2018. C. 192-201.

14. Карпенко Ю.М., Карпенко Н.Л. Імідж вищого навчального закладу: основні складові та проблеми формування. Науковий вісник Полісся. 2015. № 1(1). С. 118-124.

15. Ковальчук М.С., Сердуніч Н.В. Використання Інтернет-технологій для формування іміджу навчального закладу. Вісник Хмельницького національного університету. 2011. № 6. С. 200-202.

16. Мамай Н.В. Складові забезпечення позитивного іміджу вищого навчального. Вісник НУВГП. 2016. № 3(75). С. 102-110.

17. Холод О.М. Комунікаційні технології: підручник. Київ : КиМУ, 2011. 312 с.

\section{References}

1. Drūteikenè, G. \& Marčinskas, A. (2011). University image: new approach and perspective theoretical and practical. Ekonomika, 90 (2), .161-164 [in English].

2. Fulk, Janet (1993). Social Construction of Communication Technology. The Academy of Management Journal, 36 ( 5), 921-950 [in English].

3. P?rez, J. P. \& Torres, E.M. (2017). Evaluation of the organizational image of a university in a higher education institution. Contadur?a y Administraci?n, 62 (1), 123-140 [in English]. 
4. Sung, M. \& Yang S. (2008). Toward the Model of University Image: The Influence of Brand Personality, External Prestige, and Reputation. Journal of Public Relations Research, 20 (4), 357-376 [in English].

5. Vlăduțescu, $\square$ tefan (2013). Communicational Basis of Social Networks. International Journal of Management Sciences and Business Research, 2 (8), 1-5 [in English].

6. Ananchenkova, P.I. (2009) Improving the image as a factor in the competitiveness of higher education institutions. Candidate's thesis. Moscow [in Russian].

7. Arbuzova, Yu.V. (2014). Formation of a positive image of an educational institution. Information technology in science and production, 2 (7). Retrieved from http://sbornik.college.ks.ua/downloads/sbornik2_7/ pdf/29.pdf [in Ukrainian].

8. Bachynska, O.M. (2013). The role of the image in the structure of ensuring the competitiveness of the universities. Proceedings of the First International Scientific and Practical Internet-Conference «Topical issues of increasing the competitiveness of the state, business and education in modern economic conditions». Retrieved from http://www.confcontact.com/20130214_econ/4_bachinska.htm [in Ukrainian].

9. Vasylenko, V. (2013). Use of information resources of social networks for professionally oriented work of the university. Proceedings of the Ukrainian Scientific and Practical Internet-Conference «Problems of formation of information culture of the person». (p.180). Mariupol: MSU [in Ukrainian].

10. Volkova, V.V. (2005). Image of an educational institution in the context of the problem of university competitiveness. Collection of scientific. works of the North Caucasus State Technical University, 2. Retrieved from http://science.ncstu.ru/articles/hs/14/10.pdf/file_download [in Russian].

11. Gavra, D. Socio-communicative technologies: essence, structure, functions. Optimal communications. Retrieved from http://jarki.ru/wpress/2010/02/28/937/ [in Russian].

12. Gorbenko, N. V. (2014). Features of forming the image of the modern university. Educational discourse, 1(5), 36-43 [in Ukrainian].

13. Dyuzheva, K.V. (2018). Formation of image in the system of social communications. Socium. Document. Communication, 192-201 [in Ukrainian].

14. Karpenko, Yu.M. \& Karpenko, N.L. (2015). The image of a higher educational institution: the main components and problems of formation. Scientific bulletin Polesie, 1(1). 118-124 [in Ukrainian].

15. Kovalchuk, M.S. \& Serdunich N.V. (2011). Use of Internet technologies to form the image of an educational institution. Bulletin of the Khmelnytsky National University, 6, 200-202 [in Ukrainian].

16. Mamay, N.V. (2016). Components of providing a positive image of a higher educational institution. Bulletin of NUVGP, 3(75), 102-110 [in Ukrainian].

17. Holod, O.M. (2011). Communication technologies. Kyiv: KIU [in Ukrainian]. 